\title{
Seasonal Abundance of Onion thrips, Thrips Tabaci Lindeman. in Sokoto, Nigeria
}

\author{
Ibrahim, N. D (Corresponding author) \\ Department of Crop Science, Faculty of Agriculture, U.D.U., Sokoto, Nigeria
}

Tel: 234-080-3603-0932Ｅ-mail: dolegoronyo@yahoo.com

Adesiyun, A. A.

Department of Crop Protection, Faculty of Agriculture, University of Ilorin, Ilorin, Nigeria

E-mail: yinkaadesiyun@yahoo.com

\begin{abstract}
Onion seedlings were transplanted from November to March to study the population dynamics of onion thrips, Thrips tabaci. There are four transplants in 2001/2002 and five in 2002/2003 seasons. In 2000/2001 season onion plants were grown in exploratory trials and in 2003/2004, water traps were used to confirm results of the previous experiments. Results indicate that November transplant had a peak population of onion thrips in late February (176 thrips/plant); December (416 thrips/plant) and January (608 thrips/plant) transplants peaked in March, and February (148 thrips/plant) and March (86) transplants had peaks in April. Water traps indicate that the peak population of adult thrips was at the time of harvest in April, similar to November transplant. The early transplant (November) had peak thrips population at maturity and middle transplant recorded the peak population middle of the season and late transplant had their peaks early part of the growing season. Therefore, the findings of this work revealed that onion thrips in Sokoto, Nigeria, breed from January to May with peak in March.
\end{abstract}

Keywords: Breed, Exploratory, Peak, Season, Seedlings, Thrips tabaci, Transplant

\section{Introduction}

\subsection{Importance of Onion}

Edible alliums are important vegetables worldwide. In terms of global weight of vegetables produced, at nearly 28 million tonnes per annum, only tomatoes and cabbage exceed bulb onions in importance (FAO, 1991). The distinctive flavour of onions is appreciated by people. One of the advantages of onion is that the bulbs can be harvested and sold "green" for salads (Lannoy, 2001), while the mature bulbs are cooked or eaten raw as vegetable (Straub and Emmett, 1992).

\subsection{Onion Thrips}

Onions and related Allium crops are subject to a variety of diseases and attack by arthropod pests that can reduce crop yield and quality (Lorbeer et al., 2002). Probably the most damaging pests worldwide are the insignificant looking thrips or thunderflies. These are slender insects only about $2 \mathrm{~mm}$ long as adults. They are found wherever alliums are grown, but are most severe in the warmer production regions (Brewster, 1994). Soni and Ellis (1990) listed seven species of Thrips as allium pests, the best known of which is Thrips tabaci, the onion thrips, which attacks all edible allium. Onion thrips have a wide range and populations move from one crop to another when conditions change, such as when neighbouring crops are harvested (Shelton and North, 1986). Thus, the temporal and spatial arrival of onion thrips population into onion fields is variable and relatively unpredictable (Gangaloff, 1999).

According to Kranz et al. (1977), the number of thrips on a crop can increase rapidly in dry weather and decrease rapidly after rain. They found that large number of thrips attacking a crop at the seedling stage could cause severe or even total losses with onion, cabbage or cotton. However, once established and growing vigorously, most plants could tolerate feeding damage. Adults and nymphs were present from February to harvest (April or May) with peak abundance in early April (Edelson et al., 1986). Kranz et al. (1977) reported that control of alternative host plants is unlikely to be a useful method except under exceptional circumstances, because of wide host range. The crop may be protected by bringing forward planting date so that the maximum population of thrips does not coincide with the 
seedling stage. Earlier studies conducted on the insect pest were done in Zaria (Sub-humid zone of Nigeria) by Raheja (1973) which reported that population of thrips gradually built up and reached a peak 50 days after transplanting. Also Kisha (1977) found that few thrips were present on onion crop until mid-February when there was a sudden increase in numbers to peak levels during the first week of April, after which the numbers declined. There has been no study conducted on the seasonal abundance on the insect in this agro ecology (Dry Sub-humid) where bulk of the crop is produced. Therefore, this study was initiated with the following objectives:

(i) to study the incidence of thrips on un sprayed onion crop;

(ii) to assess changes in number of thrips on onion transplanted at different times of the growing season and

(iii) to identify the time of peak incidence and decline.

Therefore this paper reports the study conducted on the seasonal abundance of onion thrips, Thrips tabaci in Sokoto, Nigeria

\section{Materials and methods}

\subsection{Experimental Area}

Field experiments were conducted at Kwalkwalawa in Sokoto State, about $5 \mathrm{~km}$ from the main campus of Usmanu Danfodiyo University, Sokoto in the dry seasons of 2000/2001, 2001/2002 and 2002/2003 as indicated in the planting and transplanting dates below. The sites of the experiments remained the same in the three years. The area is located on latitude $13^{0} 01^{\prime}$ and longitude $05^{\circ} 15^{\prime} \mathrm{E}, 300 \mathrm{~m}$ above sea level. Onion seeds of Ex-Gidan Kwano were raised at monthly interval in the nursery for 8 weeks before transplanting. The seedlings were transplanted by placing them in to holes, made with a sharp pointed stick at nearly the same depth they were in the nursery, except in P1 in 2001/2002, where the planting did not produce enough for transplanting. Poultry manure at the rate of $10 \mathrm{t} / \mathrm{ha}$ was applied and complemented by the application of N.P.K. (15:15:15) fertilizer at 2 and urea at 6 WAT. At 2 WAT, $300 \mathrm{~kg}$ of N. P. K. was applied (45 Kg N.P.K.) and later $97.8 \mathrm{~kg} / \mathrm{ha}$ of urea $(46 \% \mathrm{~N})$. The design was randomized complete block, replicated three times. The plot size was $2.5 \mathrm{~m} \times 1.5 \mathrm{~m}$ containing 5 rows of 17 plants/ row, in a spacing of $30 \mathrm{~cm}$ between and $15 \mathrm{~cm}$ within row.

The planting and transplanting were as follows:

2001/2002 season

$P_{1}$ 18/9/2001 (no transplanting)

$\mathrm{P}_{2} 16 / 10 / 2001 ; 11 / 12 / 2001$

$\mathrm{P}_{3} 13 / 11 / 2001 ; 8 / 1 / 2002$

$\mathrm{P}_{4} \quad 11 / 12 / 2001 ; 5 / 2 / 2002$

$\mathrm{P}_{5} \quad 8 / 1 / 2002 ; 5 / 3 / 2002$
2002/2003 season

$17 / 9 / 2002 ; 12 / 11 / 2002$

$15 / 10 / 2002 ; 10 / 12 / 2002$

$12 / 11 / 2002 ; 7 / 1 / 2003$

$10 / 12 / 2002 ; \quad 4 / 2 / 2003$

$7 / 1 / 2003 ; \quad 4 / 3 / 2003$

\subsection{Sampling of Thrips from Onion Plants}

Two plants were selected by systematic sampling from the $2^{\text {nd }}$ and $4^{\text {th }}$ rows at weekly intervals from each plot and placed in a labelled polythene bag. The height of each plant was measured from ground level to the tip of the tallest leaf. The choice of systematic sampling was to avoid sampling the same plant more than once to avoid sampling a plant twice, because onion has the ability to regenerate. It was observed that on the November and December transplants it was difficult to distinguish between excised and fresh (un-sampled) plants at 8-9 WAT and the only distinguishing feature was corrugation of leaves in the sampled plants. Onion plants were cut with a sharp knife close to the ground, placed in polythene bags before they were taken to the laboratory where they were placed in a deep freezer overnight to immobilize the insects.

\subsection{Sampling of Thrips from Water Traps}

Water traps were constructed from plastic containers $16 \mathrm{~cm}$ outer and $13.5 \mathrm{~cm}$ inner diametre and $19.2 \mathrm{~cm}$ deep placed on metal plates welded to a metallic stand. The metallic stands were of sufficient length to be driven into the soil and pulled out from time to time for the trap to be adjusted to the height of the plants as the season progressed. The water traps were placed 2 metres apart in the field. This started when onion was transplanted and continued up to harvest. 
Each trap was 3/4 filled with an aqueous solution made from $20 \mathrm{ml}$ of liquid detergent and formalin, in a ratio of 1:3 in 4 litres of water. The liquid detergent was to reduce surface tension and formalin to act as a preservative (Adesiyun, 1977). The same concentration of the solution was maintained throughout the study period, as it was shown by Mayer (1961) that different concentration affects the number of insects caught. The contents of the traps were emptied into a sieve made of a fine clean cloth on weekly basis, soon after collection. The insects were collected into a vial containing $70 \%$ ethanol before examination in the laboratory under a binocular microscope.

\section{Results}

Figure 1 shows that there was only one transplant in November in 2002/2003 season, as the equivalent crop did not survive at the nursery. Thrips started colonizing the crop in December in an insignificant number until end of January when the number rose to 20/plant and finally reached a peak at harvest without declining. The possible reason for the decline in thrips population between $3^{\text {rd }}$ and $10^{\text {th }}$ April was because the February transplanting was on the $5^{\text {th }}$ February making it possible for insects to move to new plant. In the December transplant, the population was low in January and peaked in February in 2002/2003 and in 2001/2002; the peak was on $11^{\text {th }}$ March (Figure 2). Figure 3 shows that there were variations in the abundance of thrips on onion in 2000/2001, 2001/2002 and 2002/2003 seasons. It reveals that in the three seasons, thrips were first noticed on the crop in the middle of February $\left(11^{\text {th }}\right)$ and the number remained low $(<$ 5/plant) up to February 25 in 2000/2001 and 2001/2002 seasons. Thereafter, the number began to rise steeply. It peaked around March 18 in 2000/2001 season at 80 thrips/plant and about 280 thrips/plant in 2001/2002 season. It peaked earlier on March 11 at about 600 thrips /plant in 2002/2003.

In 2000/2001 and 2001/2002 seasons, the peak population of thrips occurred 6 weeks after first appearance on the crop; it took only five weeks in 2002/2003 season. The peak populations in 2000/2001, 2001/2002 and 2002/2003 seasons were 80 thrips/plant, 280 thrips/plant and 600 thrips/plant respectively. This progressive increase over three seasons may be attributed to population build-up on the piece of land over the years as these crops did not receive any spray made them very susceptible to attack.

In Figure 4 where onion plants were transplanted in February, there were two peaks in March and April in both years, though the population was slightly higher in 2001/2002 season. This could because there was a decline in January transplant, but the population rose again because already the first and second crops have been removed and only this and March crop might be producing new leaves. The population of thrips was high when onion was young and later declined (Figure 5) though there was some increase later, before finally declining at the time when the crop was ready for harvest. The possible reason for the differences in the two years in Figure 5 was November transplant provided enough breeding for subsequent crops, such as March transplant. Relative estimates of insects were obtained by the use of water traps, which were set up on a farmer's field from December to April to monitor flying thrips. Results (Figure 6) showed that catches were made from mid-December, but population of thrips remained low (less than 10 thrips/trap) until mid-March when population of more than 10 thrips/trap was recorded. The population continued to rise up to the third week of March and declined between 22 and 29 March but rose sharply to more than 70 thrips/trap by the first week of April. The experiment was terminated on April 7 because the crop was harvested two days to the sampling.

Yield of onion as presented in Figure 7 showed that between 30 and 50 t/ha was obtained when transplanting was done between months of November and December, but delaying till January results in less than $15 \mathrm{t} /$ ha because by January the population of thrips in the month was over 50 thrips/plant in untreated plot at 7 WAT (Ibrahim and Adesiyun, in press)

\section{Discussion}

The low number of thrips recorded in 2002/2003 season compared to 2001/2002 in Figure 2,4 and 5 as against Figure 3 was probably due to early presence of the onion crop in November (Figure 1), which reached up to 180 thrips /plant when already three transplantings were on the field. This agrees with the findings of Kisha (1977) that in the first season, few thrips were present until mid-February when there was sudden increase in numbers to peak levels during the first week of April. However, the highest population of over 600 thrips/plant recorded in the January transplant indicates that the population was rising yearly because of continuous cropping. Adesiyun (1981; 1982) found that damage caused by shoot flies to sorghum planted early in the season was low and insignificant. He also maintained that the low population was on the scanty vegetation during the dry season. In this study, the population of thrips was low probably because many suitable hosts were unavailable and breeding sites inundated, but since this pest is polyphagous it could have survived on the wild plants. Reuda and Shelton (2003) reported that at the end of the season, however, thrips might not be able to survive in abundance because there is not sufficient green vegetation in the surrounding areas, as April and May being the driest months of the year. They added that from June-September heavy rains maintained thrips population at low levels in native vegetation where they were not treated, i.e. living on wild flora. This is evident in Figure 3 where the peak in 2000/2001 season was less than 100 thrips/ plant, between $18^{\text {th }}$ and $25^{\text {th }}$ March, less than 300 thrips/plant in 2001/2002 season on the $11^{\text {th }}$ March, 2002 and over 600 thrips/plant in 2002/2003 season on the $11^{\text {th }}$ March, 2003. Reitz (2002) reported that populations of Frankliniella occidentalis Pergande did not reach to peak level 
until the first week of May, but their population decreased over the next three weeks. There were variations in the peak populations, which ranged from 5 WAT in the March transplant, 9 or 10 WAT in the January transplant to 13 WAT in the November transplant. This disagrees with Raheja (1973) that the peak population of onion thrips was at 50 days after transplanting, probably because he used one planting.

Salguero-Navas et al. (1991) found that host plant phenology plays an important role in population dynamics, with younger plants being able to support greater densities than older plants, but this was found to be true with onions transplanted in February and March. Earlier transplantings made in November to December had peaks towards the end of the season. Similarly, Kannon and Mohammed (2001) observed that there was a steady increase of thrips population from February and March and a sharp decline in April in 1992/93 and 1993/94 growing seasons. Kisha (1977) reported that independent of transplanting date, thrips bred only between February and April and that high temperature and low humidity from April onwards were responsible for sudden population decline. In water traps where only adult thrips were recorded, the peak populations of more than 70 thrips/trap was recorded at the time of harvest was probably due to migration into the onion, which was harvested two days to the sampling date. Another possible reason was the movement of the thrips out of the onion at the time of harvest

\section{Conclusion}

The research has given the population dynamics of onion thrips in the three years (2000-2003), and has indicated that the November transplant had peak of onion thrips at the time of harvest and the crop has therefore escaped attack, yielding up to 50t/ha, but subsequent plantings such as December, January and February transplanting had their peaks in March. Also the trend of yield was found to be very similar in both years, where significantly higher yields were obtained in November and December transplants.

\section{References}

Adesiyun, A. A. (1977). Effects of the oat crop environment on colonization by Oscinella frit L. (Diptera: Chloropidae). Ph.D. Thesis, University of London. pp 225.

Adesiyun, A. A. (1981). Seasonal abundance of shoot flies infesting sorghum and their natural enemies in Samaru, Zaria-Nigeria. Insect Science and Application, 2(2), 49-53.

Adesiyun, A. A. (1982). Effects of Dates of Planting on the Damage by shoot flies to some cultivated varieties of sorghum. Nigerian Journal of Plant Protection 6:3-9.

Brewster J. L. (1994). Onions and other Vegetable Alliums. Horticulture Research International, Wellesbourne, CAB International. pp 236.

Edelson, J. V., Cartwright, B., \& Royer, T. A. (1986). Distribution and Impact of Thrips tabaci (Thysanoptera: Thripidae) on onion. Journal of Economic Entomology, 79(2), 502-505.

FAO. (1991). Production yearbook for 1990. Food and Agriculture Organization, Rome.

Gangaloff, J. L. (1999). Population dynamics and insecticide resistance of onion thrips, Thrips tabaci L. (Thysanoptera: Thripidae), in onions. Ph.D. Thesis, Cornell University, pp 131. In: Shelton, A. M., Nault, B. A., Plate, J. and Zhao, Z. J. (2003). Regional and Temporal variation in susceptibility to lambda-cyhalothrin in onion Thrips, Thrips tabaci (Thysanoptera: Thripidae) in onion fields in New York. Journal of Economic Entomology, 96 (6), 1843-1848.

Kannon, H. O, \& Mohammed, B. (2001). The impact of irrigation frequency on population density of thrips, Thrips tabaci (Thysanoptera:Thripidae) and yield of onion in Sudan. Annals of Applied Biology, 138 (2), 129-132.

Kisha, J. S. A. (1977). Cultural and insecticidal control of Thrips tabaci on onions in the Sudan. Annals of Applied Biology 86, 219-228.

Kranz, S., Schmutterer, H., \& Koch, W. (1977). Diseases, Pests and Weeds in Tropical Crops, John Wiley and Sons, New York and Toronto. pp 666.

Lannoy, G. De. (2001). Vegetable Crops in Tropical Africa 395-511. In: Raemaeks R. H. (ed). Crop Production in Tropical Africa. pp1540. Directorate General for International Cooperation (DGIC) Belgium.

Lorbeer, J. W., Kuhar, T. P., \& Hoffmann, M. P. (2002). Monitoring and forecasting for Disease and Insect Attack in Onions and Allium crops within IPM strategies. In: Rabinowitch, H.D. and Currah, L. (Editors). Allium Crop Science: Recent Advances, pp 293-309,CABI, Wallingford, U.K.

Mayer, K. (1961). Utersuchungen uber das wahlverhalten der Fritfliege (Oscinella frit L.) beim. Anflug von Kulturpflanzen Bundesanst.Berl., 106, 47 pp. In: Rev. Appl. Ent. (H), 51,abs. 686

Raheja, A. K. (1973). Onion Thrips and their control in northern Nigeria. Samaru Agricultural Newsletter, 15(2): 82-86.

Reuda, A., \& Shelton, A. M. (2003). Development of a bioassay system for monitoring susceptibility in Thrips tabaci. Pest Management, 59 (5), 553-558. 
Salguero-Navas V.E., Funderbur, J.E, Beshear,R. J. Olson, S. M., \& Mack, T. P. (1991). Seasonal patterns of Frankliniella spp (Thysanoptera: Thripidae) in tomato flowers. Journal of Economic Entomology, 84, 1818-1822

Shelton, A. M., \& North, R. C. (1986). Species composition and Phenology of Thysanoptera within field crops adjacent to cabbage fields. Environmental Entomology, 15,513-519.

Soni, S. K., \& Ellis, P. R. (1990). Insect Pests. In: Rabinowitch, H.D. and Brewster, J.L. (eds). Onions and Allied Crops, Vol. II. Agronomy, Biotic interactions, Pathology, and Crop Protection pp $213-271$. CRC press, Boca Raton, Florida, USA

Straub, R.W. and Emmett, B. (1992). Pests of Monocotyledon Crops. In: Mc Kinlay, R.G. (Editor). Vegetable Crop Pests. Macmillan Press. U. K. p. 213-262.

Reitz, S.R. (2002). Seasonal and within plant distribution of Frankliniella thrips (Thysanoptera:Thripidae) in North Florida tomatoes. Florida Entomologist, 85(3), 431-439.

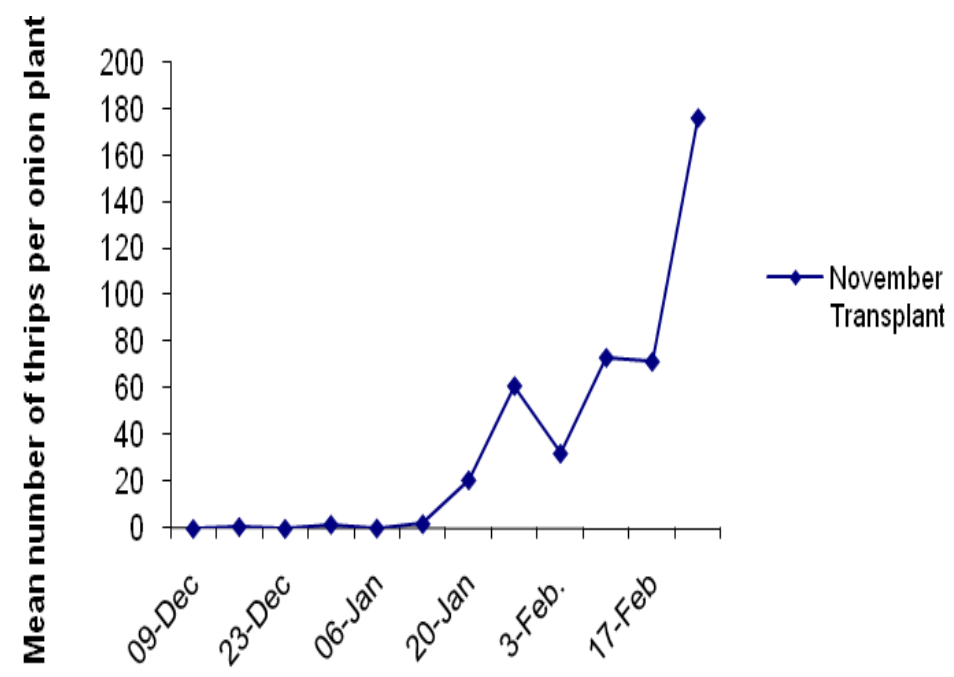

Fig: 1 Mean number of thrips per onion plant in 2002/2003 season

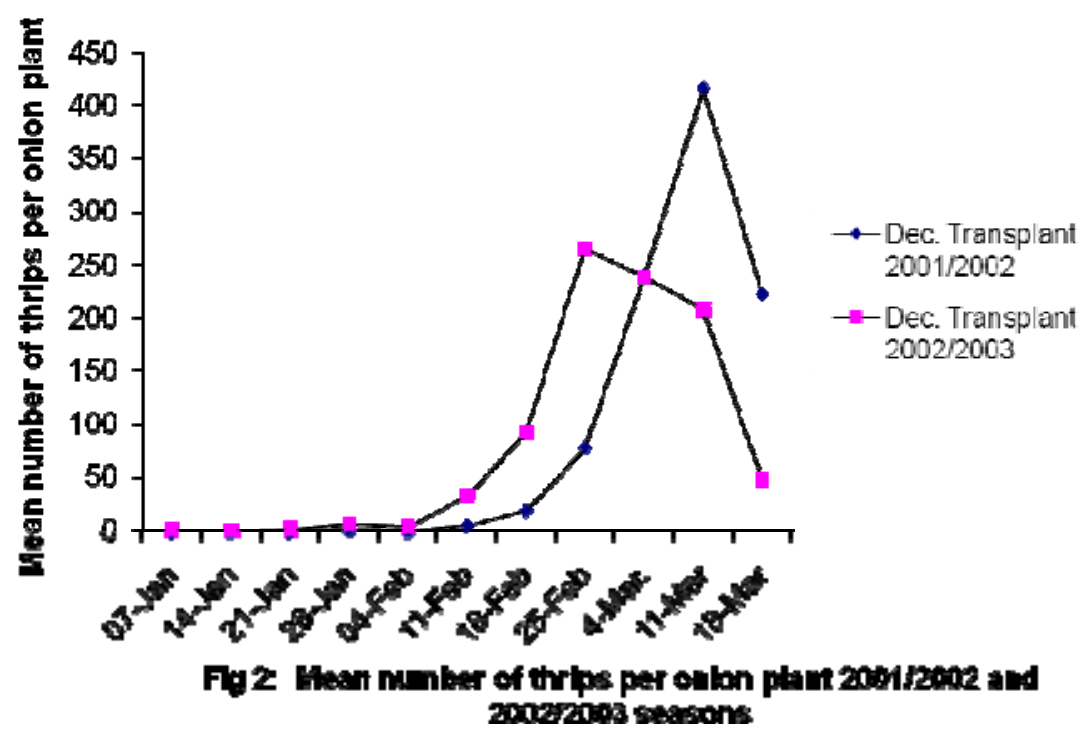




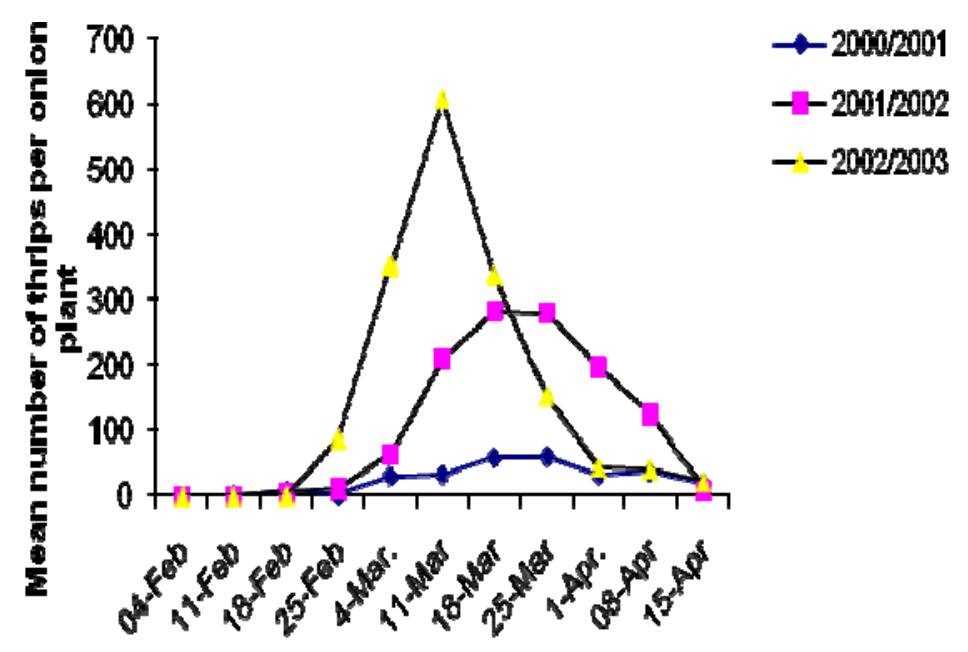

Fig 3: Hean munber of thrips per onion plant in January Iransplant in 2000/2001, 2001/2002 and 2002/2003 seasons

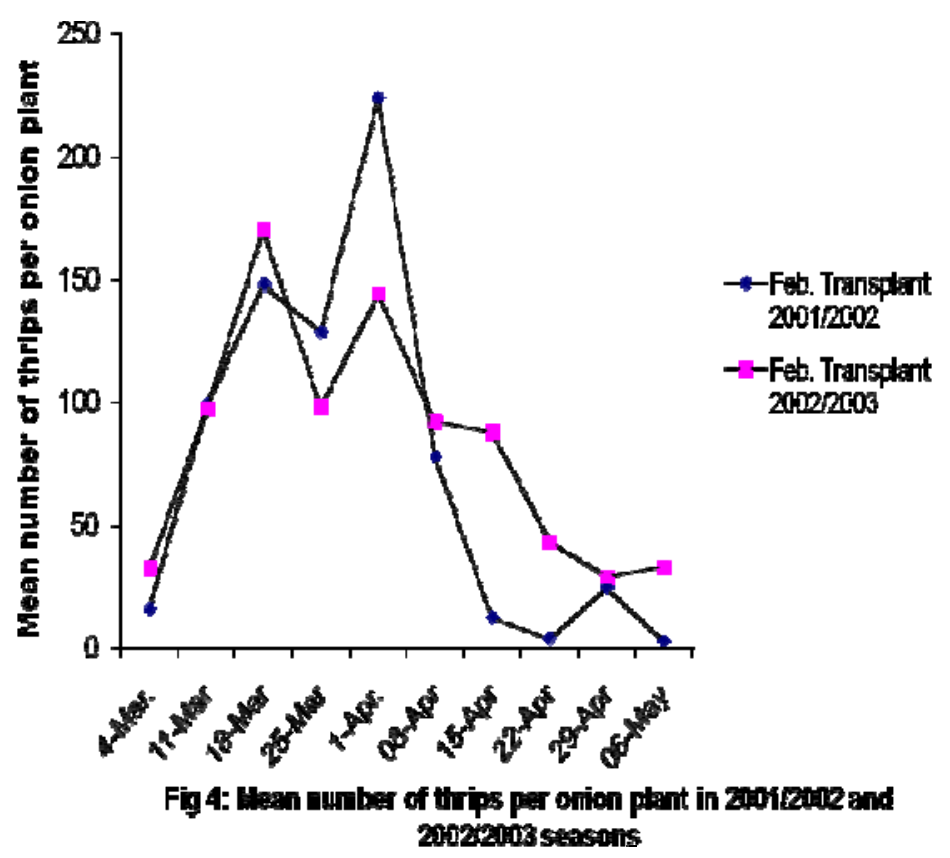




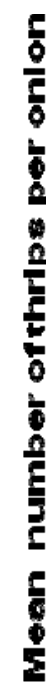

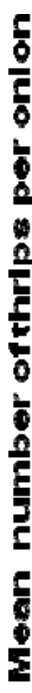

- Warch transplant 20012002

- Warchtransptant 20022003

Fig 5: Hean number of thrips per onion plant in 2001/2002 and 200222003 seasons

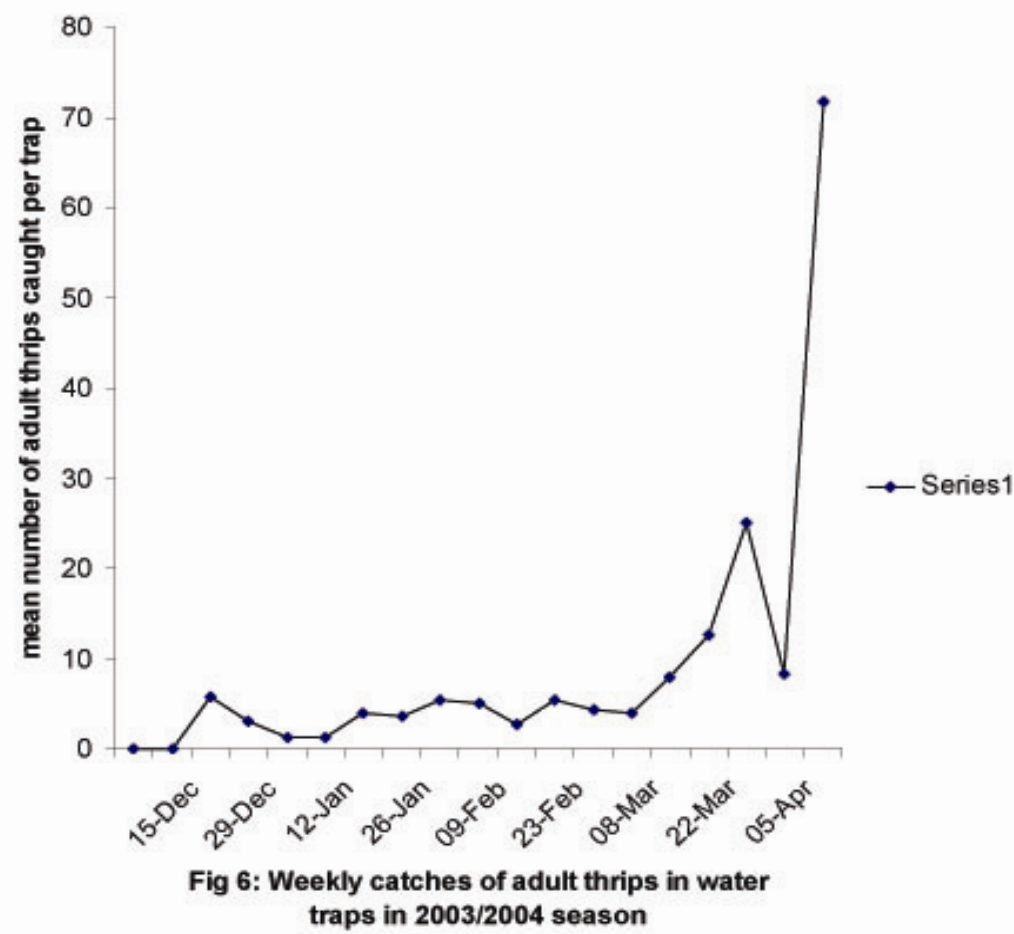




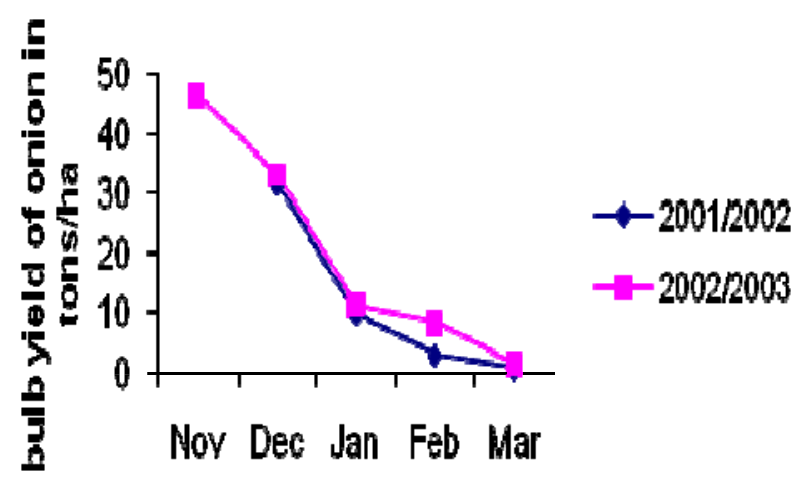

Daxe of Transplanting

Fig 7: Orion bulb yieldha in two seasons 